\title{
Long-term avian influenza virus epidemiology in a small Spanish wetland ecosystem is driven by the breeding Anseriformes community
}

\author{
Olalla Torrontegi ${ }^{1}$, Vega Alvarez ${ }^{1}$, Pelayo Acevedo ${ }^{2}$, Xeider Gerrikagoitia ${ }^{1}$, Ursula Höfle ${ }^{2}$ and Marta Barral ${ }^{1 *}$ (1)
}

\begin{abstract}
During 2007-2009 and 2012-2014, avian influenza virus (AIV) was studied in a wild avian community of a northern Spanish wetland using non-invasive sampling methods and host identification by COI barcoding. The aim of this longitudinal study was to evaluate AIV dynamics in a natural wetland ecosystem, taking into account both virological aspects and ecological traits of hosts. Global AIV prevalence decreased significantly during the second sampling period (0.3\%) compared to the first (6.6\%). Circulating subtype distributions were also different between periods, with a noteworthy $\mathrm{H} 5$ and $\mathrm{H} 7$ subtype richness during the first sampling period. Mallard Anas platyrhynchos was identified as the main AIV host, although not all positive samples could be ascribed to the host. We modelled AIV prevalence with regard to the avian host community composition and meteorological data from the wetland. Statistical analysis revealed seasonal differences in AIV detection, with higher prevalence during the breeding season compared to other phenological events. The model also shows that the lower AIV prevalence during the second study period was associated with a significant reduction of breeding Anseriformes in the wetland, revealing a long-term fluctuation of AIV prevalence driven by the breeding Anseriformes community. This longitudinal study on AIV epidemiology in a natural ecosystem reveals that although prevalence follows seasonal and annual patterns, long-term prevalence fluctuation is linked to the breeding community composition and size. These results are relevant to understanding the influence of host ecology on pathogen transmission for preventing and managing influenza emergence.
\end{abstract}

\section{Introduction}

Avian influenza viruses (AIV; family Orthomyxoviridae, genus Influenzavirus $A$ ) owe their diversity to the antigenic properties of two surface glycoproteins [16 known haemagglutinin variants (HA) and 9 neuraminidases (NA)], that combined lead to 144 potential HA/ NA subtypes [1]. Although most AIV subtypes are low pathogenic (LPAIV) to wild birds and poultry, $\mathrm{H} 5$ and $\mathrm{H} 7$ subtypes can become highly pathogenic (HPAIV) after infecting domestic gallinaceous birds [2,3]. Occasionally,

\footnotetext{
*Correspondence: mbarral@neiker.eus

${ }^{1}$ Animal Health Department, NEIKER-Instituto Vasco de Investigación y Desarrollo Agrario, Parque tecnológico de Bizkaia P-812, 48160 Derio, Bizkaia, Spain

Full list of author information is available at the end of the article
}

some AIV strains may also become zoonotic [4]. Therefore, also LPAIV need to be under stringent surveillance as they pose a risk to both animal and public health. The Asian A/goose/Guangdong/1/96 HPAIV H5N1 is a good example of geographical dispersal and interspecies transmission capacity of AIV. Until 2005, it was considered an Asian phenomenon, but in 2006 it expanded westwards reaching Europe and Africa. Ever since, HPAIV H5N1 has been present in more than 60 countries, fatally affecting birds with occasional spillovers to mammals (humans included) and its circulation still continues to the present day [5]. More recently, in 2014, an Asian HPAIV H5N1-derived HPAIV H5N8 emerged in Europe and it was thought to cause only mild disease in wild birds [5]. The HPAIV H5N8 strain concurrently spread in Siberia, South Korea, Japan and the United States [6] and by

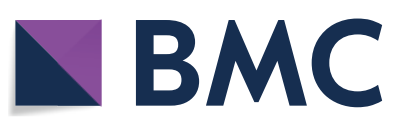

(c) The Author(s) 2019. This article is distributed under the terms of the Creative Commons Attribution 4.0 International License (http://creativecommons.org/licenses/by/4.0/), which permits unrestricted use, distribution, and reproduction in any medium, provided you give appropriate credit to the original author(s) and the source, provide a link to the Creative Commons license, and indicate if changes were made. The Creative Commons Public Domain Dedication waiver (http://creativecommons.org/ publicdomain/zero/1.0/) applies to the data made available in this article, unless otherwise stated. 
August 2017 at least 1112 HP H5N8 outbreaks in poultry and 955 in wild birds had been detected in 30 European countries, the largest epizootic detected in the continent [7]. Most H5N8 outbreaks in domestic and wild birds were small, of the size of $30 \mathrm{~km}$ radius, possibly linked between them, and it is believed that wild birds have played a role in the introduction of AIV into Europe [7].

The avian orders Anseriformes and Charadriiformes are considered the natural reservoirs of AIV [8]. Most known subtypes have been found in species of these orders in which infections tend to occur in the absence of clinical signs $[9,10]$. Particularly, the presence of Anseriformes is considered essential for AIV transmission and environmental persistence [2]. Among all the Anseriformes taxa, the mallard (Anas platyrhynchos) is the most well studied species and seems to have a key role in AIV epidemiology in natural settings in the Northern Hemisphere [11]. Mallards harbour the highest AIV subtype diversity, prevalence is usually high and most viral isolations are recovered from this taxon [10]. However, introduction of AIV can also occur occasionally by other (spillover) hosts, making ecological approaches at the wild bird community level fundamental in AIV epidemiology [12, 13].

AIV prevalence in wild ecosystems is dynamic and dependent on a wide variety of factors such as time of the year, environment, location, circulating subtype and infected host species [2, 14-17]. Epizootics in Europe are related to seasonal patterns of host species [18] and tend to be more frequent in late summer/early autumn, albeit varying in time with latitude $[8,19]$. While seasonal patterns appear consistent, significant interannual variations exist $[18,20]$. Within the Anseriformes, AIV prevalence has been associated with premigrational staging and high concentrations of juveniles (with up to $30 \%$ of infection rates within this age group), presumably due to their naïve immune system $[8,19]$. Some authors have noted that once in wintering areas, prevalence rapidly decreases, probably as a consequence of acquired herd immunity [21-23]. Heterosubtypic immunity also seems to influence the prevalence and dynamics of different AIV subtypes in hosts such as the mallard [24]. Wintering individuals have demonstrated to be able to amplify locally circulating AIV and phylogeography has shown AIV to switch from intraspecific to interspecific transmission in wintering quarters, probably as part of the AIV persistence strategy [18, 22, 25]. Transmission between hosts fundamentally occurs through the faecaloral route after shedding AIV infected particles in faeces to water bodies, with considerable variation in environmental persistence between subtypes $[19,26]$. For this reason, long-term studies are of special interest when conducting AIV monitoring in aquatic ecosystems. Yet, the existing studies are still scarce and very heterogeneous $[14,17,20,27-29]$; while some aim a single avian order (or even taxon), others have been conducted during specific periods of the year, or focused on different sampling locations sometimes with low representative samplings [10, 17, 20, 30, 31]. Consequently, comparable epidemiological results from natural environments are difficult to obtain. Given the relatively high AIV prevalence previously found in the Salburua wetland [2], a better understanding on AIV dynamics and epidemiology will only be achieved by long-term studies which consider the local wild avian host community and its ecology.

The aim of this longitudinal study was to evaluate AIV dynamics in a natural wetland ecosystem, by taking into account virological aspects and ecological traits of hosts during two different sampling periods. Our sampling strategy was based on non-invasive sampling methods, which consisted of environmental fresh faecal sample collection after de visu identification of host and flushing [and further host identification by mitochondrial cytochrome oxidase subunit 1 (COI) barcoding]. Hence, all roosting waterbird species were regarded as potential hosts and interspecies natural mixing was considered. Special attention was paid to circulating viral strains, to host species harbouring AIV and to ecological factors with a potential effect on viral detection.

\section{Materials and methods}

\section{Study area}

Salburua wetland $\left(42^{\circ} 51^{\prime} \mathrm{N} \quad 002^{\circ} 39^{\prime} \mathrm{W}\right.$; altitude $500-$ $510 \mathrm{~m}$ ) is a 217.46 ha wetland area located in Basque Country that pertains to the "Northern-Plateau" bioregion of Spain [32]. Under the Atlantic climate influence, Salburua wetland has a noteworthy thermal oscillation along the year with dry summers (infrequent precipitation, reduced relative humidity and high diurnal temperatures). Annual mean temperature is $11.4{ }^{\circ} \mathrm{C}\left(5.1{ }^{\circ} \mathrm{C}\right.$ in winter and $17.9^{\circ} \mathrm{C}$ in summer, with large temperature differences between day and night in this season) and the annual mean precipitation is $823.4 \mathrm{~mm}$. The number of ground frost days is moderate (40.8 days/year) [33].

Salburua wetland is composed of various lagoons surrounded by meadows and a small oak grove. It received the Wetland of International Importance Ramsar designation in 2002 and Site of Community Importance in 2004 within the European Natura 2000 Network. From an ornithological perspective, the wetland is strategically situated, as many bird species use these lagoons for wintering, breeding or for stopover along the East Atlantic flyway while migrating. The bird community on Salburua wetland includes mallards, coots (Fulica atra), Northern shovelers (Anas clypeata), white storks (Ciconia ciconia), gadwalls (Mareca strepera), common teals (Anas crecca), 
common pochards (Aythya ferina), common moorhens (Gallinula chloropus) crested grebes (Podiceps cristatus) and little grebes (Tachybaptus ruficollis), with varying numbers depending on the season, especially for migratory species. Since 2005, when monitoring plans for AIV began in the Basque Country, this wetland has had a frequent LPAIV record and the only HPAIV H5N1 wild bird case in the Iberian Peninsula so far $[2,12]$.

\section{Sample collection}

Collection of fresh avian faeces started at dawn, at roosting sites of waterbirds that included nine scattered islets in the wetland and seven wet meadow areas, covering almost all the available surface used by waterbirds. The number of places sampled each month was determined by the flood level of the lagoons. The species that most frequently used these roosting areas were various species of ducks, geese, storks, grey herons, coots, gulls and Eurasian spoonbills, generally as mixed flocks of varying size throughout the year. In order to minimise the risk of sampling the same bird more than once, we were careful to collect only recently deposited droppings, placing the complete dropping in an individual sterile container. Samples were kept refrigerated until analysis within the next $24 \mathrm{~h}$. As the study wetland had been part of a comparative study on ecological drivers of AIV prevalence in different wetlands [2], faecal samples, AIV isolates and bird census data were still available for the former study period (2007-2009). We submitted the available material to complementary analysis (virus subtyping and host identification), obtaining a dataset to compare host population and AIV specific data, between a former period of high LPAIV prevalence with a latter period of significantly lower prevalence. In the former period, samplings were performed once every three months during 20072009 , with a total of 667 samples obtained from eight sampling visits, from which 44 were AIV-positive (6.6\%) (for details see [2]). As for the latter sampling period, a total of 2725 samples were collected from March 2012 until September 2014 during 31 monthly sampling visits.

\section{AIV detection}

Four to five individual faecal samples were pooled according to species (when possible), appearance and location from where they were found. Viral RNA extraction was performed with a commercial kit (RNeasy Mini Kit, Qiagen, Hilden, Germany) following the manufacturer's instructions. Samples were screened with a TaqMan ${ }^{\text {TM }}$ (ThermoFisher Scientific Inc., Waltham, USA) real time reverse transcription polymerase chain reaction (rRTPCR) for AIV matrix-gene detection [34]. Amplification was carried out using AgPath-ID ${ }^{\mathrm{TM}}$ One-Step RT-PCR Reagents (ThermoFisher Scientific Inc., Waltham, USA).
At detection of an AIV-positive pool, a new individual RNA extraction from the pool-composing units was performed in an attempt to identify the positive sample by rRT-PCR.

The same viral detection procedure and reagents were used for both sampling periods.

\section{AIV isolation}

AIV isolation was performed from rRT-PCR positive samples, including individual faecal samples or pools when the AIV-positive unit could not be identified. Approximately $25 \mathrm{mg}$ of the original faecal samples were homogenised with $500 \mu \mathrm{L}$ of Hank's Balanced Salt Solution supplemented with penicillin $(2000 \mu / \mathrm{mL})$, streptomycin $(2 \mathrm{mg} / \mathrm{mL})$ and sodium bicarbonate 7.5\%, final pH 7.0-7.4 (ThermoFisher Scientific Inc., Waltham, USA). The mixture was inoculated into the allantoic cavity of five embryonated specific pathogen free (SPF) eggs after 9-11 days of incubation according to standard procedures [35]. Viral RNA extraction was carried out by incubation at $58{ }^{\circ} \mathrm{C}$ for $1-3 \mathrm{~h}, 180 \mu \mathrm{L}$ of the allantoic fluid, $2.7 \mu \mathrm{L}$ carrier RNA $(1 \mu \mathrm{g} / \mu \mathrm{L})$ and $20 \mu \mathrm{L}$ Proteinase $\mathrm{K}(20 \mathrm{mg} / \mathrm{mL})$ followed by extraction in a Biosprint 96 robot with a DNA Blood kit (Qiagen, Hilden, Germany) following the manufacturer's instructions. Samples were analysed for the presence of AIV matrix gene by rRT-PCR [34]. In cases where no AIV was isolated, the harvested allantoic fluid was reinoculated into a new set of SPF eggs and processed as previously described.

\section{AIV subtype identification and pathogenicity}

HA and NA were determined from both faecal RNA and isolates either by rRT-PCR [34, 36-39]. Pathogenicity of the H5- and H7-positive samples was determined by the haemagglutinin cleavage site sequencing [40-42].

\section{Host identification}

Host identification was only attempted for AIV positive faecal samples. DNA was extracted from these samples using MagMAX ${ }^{\mathrm{TM}}$ Total Nucleic Acid Isolation Kit (ThermoFisher Scientific Inc., Waltham, USA) according to the manufacturer's instructions. It consisted of a nested PCR targeting the COI gene. AWCF1 and AWCR6 primers were used for the first round and AWCintF4 and AWCintR6 for the second round [43]. Alternatively, first round External F1 and External R1 [44] primers were used combined with the former second round primers. The $277 \mathrm{bp}$ amplified PCR fragments were purified using Illustra $^{\mathrm{TM}}$ ExoProStar $^{\mathrm{TM}}$ 1-Step (GE Healthcare Europe, Freiburg, Germany) according to the manufacturer's instructions, and were sequenced in an AB3130 Genetic Analyzer (ThermoFisher Scientific Inc., Waltham, USA), using BigDye ${ }^{\circledR}$ Terminator v3.1 Cycle (ThermoFisher Scientific Inc., Waltham, USA). The obtained sequences 
were compared with those published on the network server of the National Centre for Biotechnology Information with BLAST ${ }^{\circledR}$.

\section{Longitudinal epidemiological analysis Ecological data}

Wetland authorities provided monthly data of bird species' abundance from the whole wetland area. Each of the censuses was performed by the same wetland officer within a single day in order to minimise bias related to observer skills or repeated counts. Counts were performed early in the morning, but not at dawn to ensure to include individuals spending the night elsewhere (mainly A. platyrhynchos). The counting method used consisted of a series of fixed observing points, from which the observer counted all relevant birds in a sector of the lagoon. For that end, $8 \times 30$ binoculars and a $20 \times 60$ magnifying telescope were used. Data of waterbird counts were grouped (Table 1) according to the following: species taxonomy; taxonomic implication on AIV epidemiology (Anseriformes and Charadriiformes reservoir hosts or not); interspecies feeding associations (grazers, gulls and divers), bird species pertaining to the Anatinae subfamily were also grouped according to surface water or diving feeding behaviour (dabbling ducks vs. diving ducks). In parallel, waterfowl phenological traits in the area (wintering season: November-January; northward spring migration: February-April; breeding season: May-July and southward autumn migration: August-October) [45] were taken into account for species categorization. In this regard, counted species were labelled as resident, winterer, breeder or migrant (depending on species more than one category could be assigned, as an example, in mallards in addition to the resident local population many individuals, mostly from central, but also from northern Europe are present during the wintering period) according to local information [46, 47] and L. Lobo's personal communications. During 2010

Table 1 List of predictors related to the avian community inhabiting the Salburua wetland used for building the model

\begin{tabular}{|c|c|}
\hline Predictor & Definition \\
\hline Census of wild birds & Total wild bird counts per census session (monthly) \\
\hline Species richness & Number of wild bird species \\
\hline Order & $\begin{array}{l}\text { Counts of waterbird per orders (Anseriformes, Charadriiformes, Ciconiiformes, Gruiformes, Pelecaniformes, } \\
\text { Podicipediformes) }\end{array}$ \\
\hline Species & Counts of waterbird per species \\
\hline Anseriformes and Charadriiformes & Counts of Anseriformes and Charadriiformes individuals \\
\hline non-Anseriformes and non-Charadriiformes & Counts of non-Anseriformes and non-Charadriiformes individuals \\
\hline Anatini & Counts of dabbling ducks \\
\hline Aythyini & Counts of diving ducks \\
\hline Grazers & Counts of Anas penelope, Anas crecca, Anser anser and Fulica atra \\
\hline Gulls & Counts of Larus michahellis, Larus fuscus and Chroicocephalus ridibundus \\
\hline Divers & Counts of Aythya ferina, Aythya fuligula and Fulica atra \\
\hline$\underline{\text { Phenology }}$ & $\begin{array}{l}\text { Waterfowl life cycle events: northward spring migration, breeding, southward autumn migration, } \\
\text { wintering }\end{array}$ \\
\hline Breeding couples & $\begin{array}{l}\text { Counts of breeding couples per species (Anas clypeata, Anas platyrhynchos, Anas strepera, Anser anser, } \\
\text { Aythya ferina, Aythya fuligula, Ardea cinerea, Ardea purpurea, Ciconia ciconia, Circus aeruginosus, Charadrius } \\
\text { dubius, Fulica atra, Gallinula chloropus, Himantopus himantopus, Ixobrychus minutus, Larus michahellis, } \\
\text { Nycticorax nycticorax, Podiceps cristatus, Rallus aquaticus and Tachybaptus ruficollis) }\end{array}$ \\
\hline Breeding Anseriformes & Counts of breeding couples of Anseriformes members \\
\hline $\begin{array}{l}\text { Breeding non-Anseriformes and non- } \\
\underline{\text { Charadriiformes }}\end{array}$ & Counts of all breeding couples excluding Anseriformes and Charadriiformes \\
\hline Summer visitor birds & Counts of summer visitor birds \\
\hline$\underline{\text { Summer visitor species richness }}$ & Number of summer visitor species \\
\hline Winter visitor birds & Counts of winter visitor birds \\
\hline Winter visitor species richness & Number of winter visitor species \\
\hline Migratory birds & Counts of migratory birds \\
\hline Migratory species richness & Number of migratory species \\
\hline Resident birds & Counts of resident birds \\
\hline$\underline{\text { Resident species richness }}$ & Number of resident species \\
\hline
\end{tabular}

$\mathrm{VIF}<2$ in underline.

a Wintering: November-January; northward spring migration: February-April; breeding: May-July and AM southward autumn migration: August-October. 
and 2011 bird censuses were performed but no samples for AIV detection were taken. During breeding season, an additional census was performed by the same wetland officer as in the monthly censuses. This encompassed the whole wetland area and consisted of nest counting to infer the minimum number of breeding couples at the Salburua wetland. Daily meteorological parameters from sampling day, 7 and 15 days before sampling (bs) were obtained from the Basque Meteorological Agency (Euskalmet) (Table 2) and added to the dataset [48].

\section{Statistical analysis}

We used the number of AIV-positive samples at each sampling visit (35 sampling visits; 8 for 2007-2009 and 27 for 2012-2014) in relation to sample sizes as the response variable. A generalized linear model (GLM) (binomial distribution, logit link function) was used to assess the effects of ecological factors (namely, phenology, bird counts and climate; see below) explaining variations in AIV positivity in this longitudinal study. In addition to the aforementioned variables, predictors previously described (Tables 1 and 2) were included as covariables. We avoided multicollinearity derived problems using the variance inflation factor (VIF); covariables with VIF $>2$ were not considered for modelling [49]. VIFs were calculated for each variable as the inverse of the coefficient of non-determination of the regression of each predictor against all others using the R package "HH" [50]. The variables selected after controlling the VIF were considered in the GLM. The final model was obtained using a forward-backward stepwise procedure based on the corrected Akaike Information Criteria to compare models. The Post-hoc Tukey's test was performed to assess for differences between pairs of phenological periods. Differences were considered significant when $p<0.05$.

Table 2 List of predictors related to the meteorological data that were used for building the model

\begin{tabular}{ll}
\hline Predictor & Definition \\
\hline Mean temperature $\left({ }^{\circ} \mathrm{C}\right)$ & Sampling day, 7 days bs and 15 days bs \\
Maximum temperature $\left({ }^{\circ} \mathrm{C}\right)$ & Sampling day, 7 days bs and 15 days bs \\
Minimum temperature $\left({ }^{\circ} \mathrm{C}\right)$ & Sampling day, 7 days bs and 15 days bs \\
Total precipitation $\left(\mathrm{l} / \mathrm{m}^{2}\right)$ & Sampling day, 7 days bs and 15 days bs \\
Mean humidity $(\%)$ & Sampling day, 7 days bs and 15 days bs \\
Mean wind $(\mathrm{km} / \mathrm{h})$ & Sampling day, 7 days bs and 15 days bs \\
Maximum gust of wind $(\mathrm{km} / \mathrm{h})$ & Sampling day, 7 days bs and 15 days bs \\
\hline VIF<2 in italics. & \\
bs: before sampling. &
\end{tabular}

\section{Results}

AIV prevalence and subtype richness

A total of 2725 faecal samples were collected during 2012-2014. Global AIV prevalence was 0.3\% (8/2725), which was significantly lower when compared to the 2007-2009 period 6.6\% (44/667) (GLMz: Z=-8.04, $p<0.001$ ) (Table 3). Sampling effort and AIV prevalence detected at each sampling time are detailed in an additional file (Additional file 1). Viral recovery-rate from both sampling periods was 48\% (25 virus isolations out of the 52 AIV positive records). AIV isolations were only achieved from samples taken during autumn migration (Table 4).

Considering both sampling periods, 2007-2009 and 2012-2014, 11 different viral subtypes were identified (Table 4). H3N8 was the most frequent subtype (25\% of all AIV-positive samples, 13/52) followed by H11N9 $(17 \%, 9 / 52)$. A high diversity of circulating low pathogenic H5 (PQRETR*GLF) and H7 (PEIPKGR*GLF) strains was found (Table 4).

Host identification was successful in $48 \%$ (25/52) of the AIV-positive samples (Table 4). All identified host species were anatids [Anas platyrhynchos: 44\% (23/52); and Anser anser: $3.8 \%$ (2/52)].

\section{Longitudinal study}

After VIF analysis, the following variables were selected for modelling: number of migratory species, resident species richness, summer visitor species richness, number of breeding moorhen couples (Gallinula chloropus), breeding grebe couples (Podiceps cristatus), breeding little grebe couples (Tachybaptus ruficollis), breeding Anseriformes, and breeding non-Anseriformes/nonCharadriiformes (Table 1 and Figure 1). Mean humidity of sampling day and 7 days bs, total precipitation of sampling day and 15 days bs, maximum gust of wind of sampling day, mean wind 15 days bs, and phenology were also considered for building our model (Tables 1, 2 and Additional file 2). The final model explains $95.7 \%$ of the total deviance. The results indicate a strong positive relation between AIV prevalence and the number of Anseriformes breeding couples (see Table 5). There was also a positive relation with wind during the 15 days bs, with resident species richness and with breeding season. In addition to these variables, the Tukey test showed significant differences in AIV prevalence according to waterbird phenology; namely higher prevalence rates during breeding season followed by autumn migration, while AIV was less prevalent during wintering season and spring migration (with no significant differences between autumn migration and wintering neither between wintering and spring migration periods) (Figure 2). 


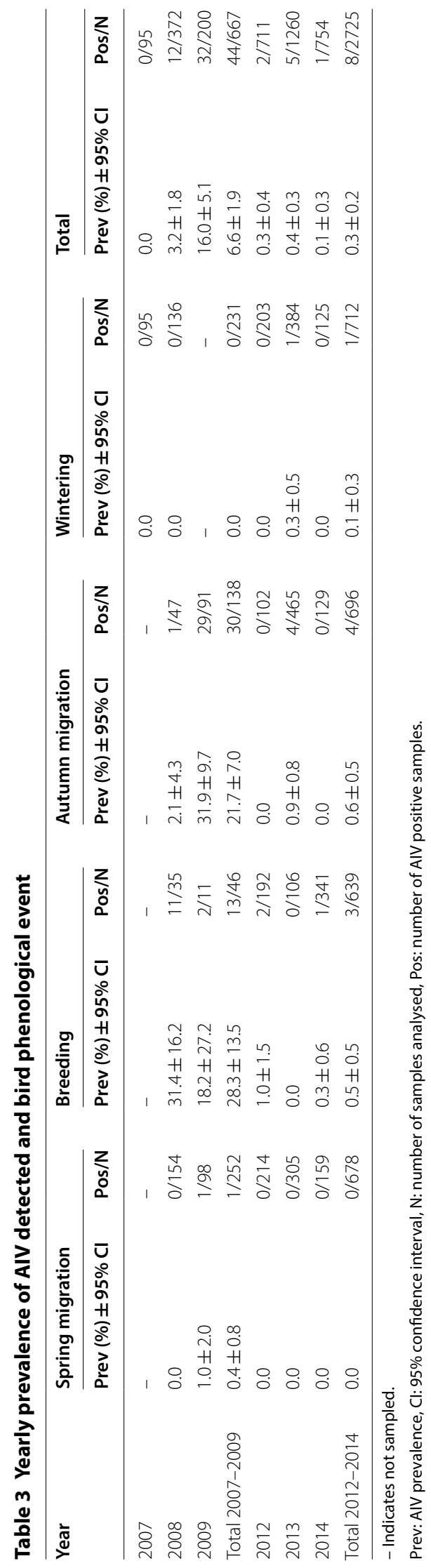


Table 4 Distribution of AIV subtypes in Salburua according to waterbird phenology, year, isolation and host species

\begin{tabular}{|c|c|c|c|c|c|}
\hline Year & Phenology & $\mathbf{N}$ & Isolation N & Subtype & Identified host (N) \\
\hline \multirow[t]{2}{*}{2008} & $B R$ & 11 & 8 & H3N8 & Anas platyrhynchos (7), ND (4) \\
\hline & AM & 1 & 0 & $\mathrm{H} 5 \mathrm{~N} 2$ & Anas platyrhynchos (1) \\
\hline \multirow[t]{13}{*}{2009} & SM & 1 & 0 & ND & $\mathrm{ND}(1)$ \\
\hline & $\mathrm{BR}$ & 2 & 0 & ND & ND (2) \\
\hline & AM & 1 & 1 & H4N? & $\mathrm{ND}(1)$ \\
\hline & AM & 1 & 0 & H6N5 & ND (1) \\
\hline & AM & 2 & 2 & H7N2 & Anas platyrhynchos (1), ND (1) \\
\hline & AM & 1 & 0 & H7N8 & Anas platyrhynchos (1) \\
\hline & AM & 1 & 1 & H7N9 & Anas platyrhynchos (1) \\
\hline & AM & 4 & 1 & $\mathrm{H} 7 \mathrm{~N} ?$ & Anas platyrhynchos (2), ND (2) \\
\hline & AM & 4 & 3 & $\mathrm{H} 11 \mathrm{~N} 2$ & ND (4) \\
\hline & AM & 9 & 6 & H11N9 & Anas platyrhynchos (4), ND (5) \\
\hline & AM & 3 & 0 & $\mathrm{H} 11 \mathrm{~N} ?$ & Anas platyrhynchos (2), ND (1) \\
\hline & AM & 1 & 1 & $\mathrm{H} 7 / \mathrm{H} 11 ; \mathrm{N} 4 / \mathrm{Ng}^{\mathrm{a}}$ & $\mathrm{ND}(1)$ \\
\hline & AM & 2 & 0 & ND & Anas platyrhynchos (1), ND (1) \\
\hline Total 2008-2009 & & 44 & 23 & & 20 \\
\hline \multirow[t]{2}{*}{2012} & $\mathrm{BR}$ & 1 & 0 & $\mathrm{H} 3 \mathrm{~N} 8$ & Anser anser (1) \\
\hline & $\mathrm{BR}$ & 1 & 0 & ND & $N D^{b}(1)$ \\
\hline \multirow[t]{5}{*}{2013} & AM & 1 & 1 & $\mathrm{H} 3 \mathrm{~N} 2$ & Anas platyrhynchos (1) \\
\hline & AM & 1 & 1 & H3N8 & ND (1) \\
\hline & AM & 1 & 0 & $\mathrm{H} 12 \mathrm{~N} 5$ & Anas platyrhynchos (1) \\
\hline & AM & 1 & 0 & ND & $\mathrm{ND}(1)$ \\
\hline & W & 1 & 0 & $\mathrm{H} 5 \mathrm{~N} ?$ & Anas platyrhynchos (1) \\
\hline 2014 & $\mathrm{BR}$ & 1 & 0 & ND & Anser anser (1) \\
\hline Total 2012-2014 & & 8 & 2 & & 5 \\
\hline Total & & 52 & 25 & & 25 \\
\hline
\end{tabular}

AM: southward autumn migration, BR: breeding season, SM: northward spring migration, W: wintering season, N: number of samples, ND: not determined, ?: not identified.

a A mixed infection, it was not possible to elucidate what haemagglutinin type corresponded to its respective neuraminidase.

b This sample pertains to a pool from 3 Fulica atra and 1 Anser anser, but whose positive unit was not possible to determine.

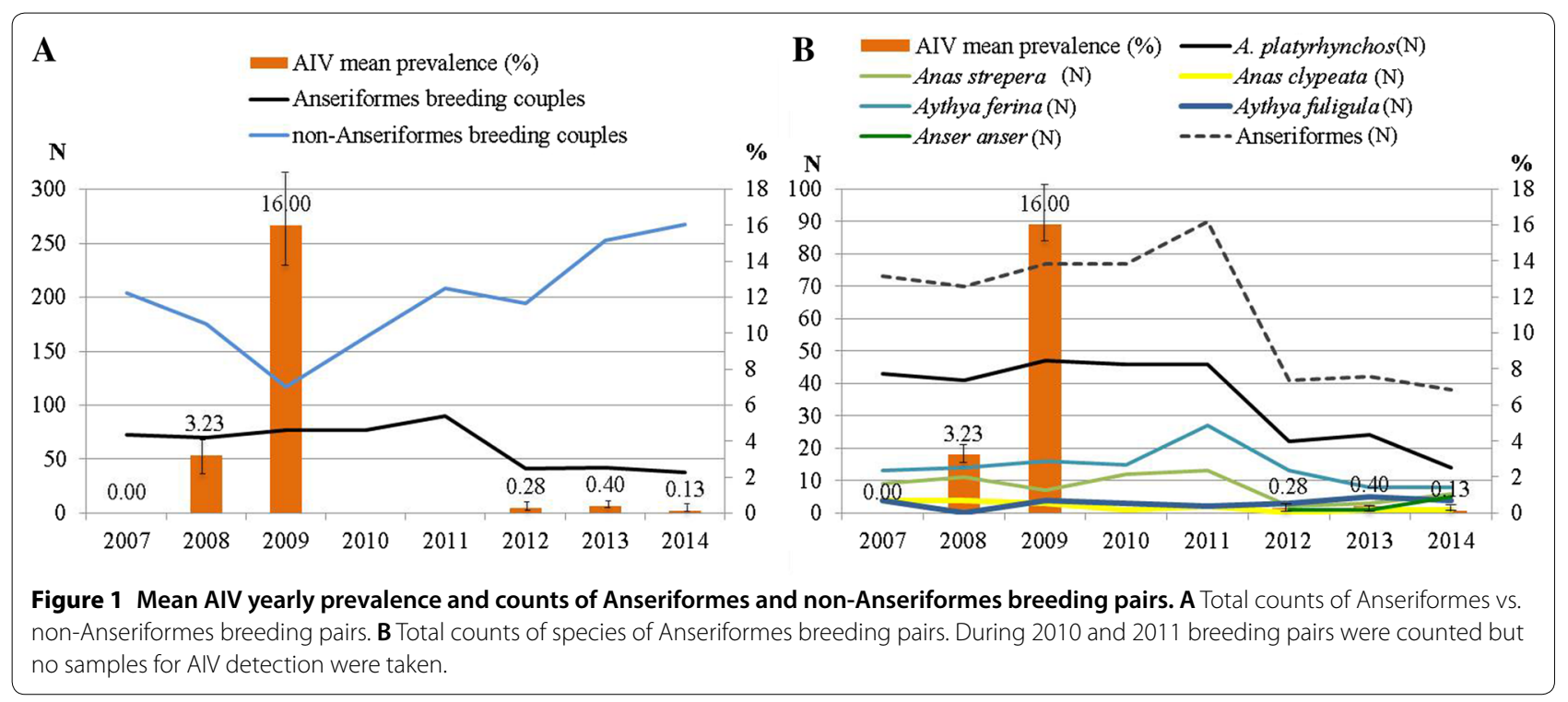


Table 5 Variables in the final model for AIV prevalence, their coefficients, statistical test value and significance

\begin{tabular}{lrrrl}
\hline & Estimate & SE & z value & $\operatorname{Pr}(>|\mathbf{z}|)$ \\
\hline (Intercept) & -37.586 & 7.832 & -4.799 & $* * *$ \\
Breeding Anseriformes couples & 0.140 & 0.024 & 5.934 & $* * *$ \\
Phenology & & & & \\
Breeding & 2.755 & 1.018 & 2.706 & $* *$ \\
Spring migration & -6.862 & 1.307 & -5.252 & $* * *$ \\
Wintering & -3.195 & 1.522 & -2.099 & $*$ \\
Resident species richness & 1.111 & 0.316 & 3.521 & $* * *$ \\
Mean wind 15 days bs (km/h) & 0.965 & 0.282 & 3.425 & $* * *$ \\
Breeding Podiceps cristatus couples & -0.193 & 0.090 & -2.140 & $*$ \\
\hline
\end{tabular}

Coefficients for phenology are relative to southward autumn migration. SE: standard error, bs: before sampling

${ }^{* * *} p<0.001 ;{ }^{* *} p<0.01 ;{ }^{*} p<0.05$.

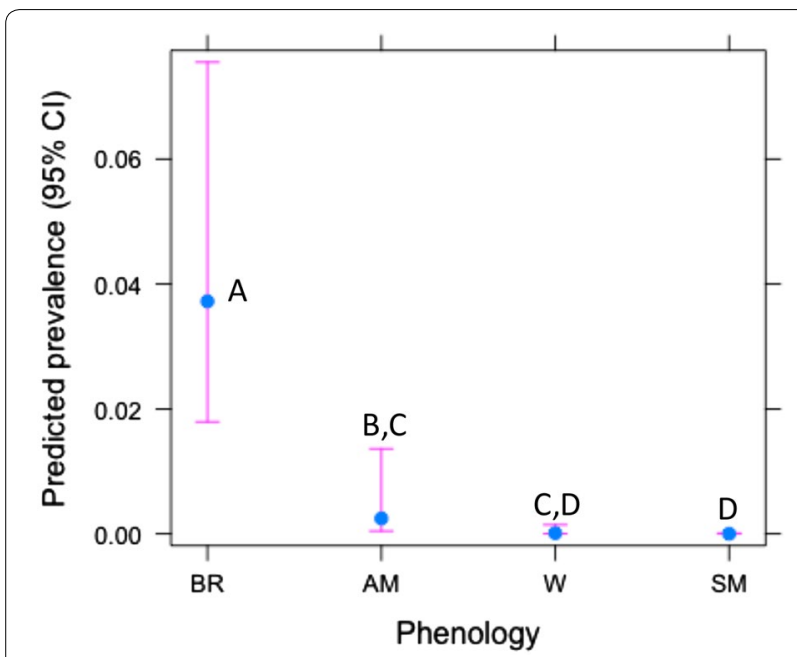

Figure 2 Predicted AIV prevalence in relation to phenology. $B R$ breeding season, AM southward autumn migration, $W$ wintering, SM northward spring migration. Means sharing the same letter did not differ significantly (Tukey tests $p>0.05$ )

\section{Discussion}

Our study provides information on the relation between long-term AIV prevalence variation and a number of ecological and environmental drivers (including Anseriformes host demography) in a small wetland in northern Spain and adds to the still scarce information on longterm AIV dynamics. The present work is a continuation to a short-term cross-sectional study that characterised several different wetlands in parallel. That study, compared factors that modulated LPAIV prevalence in a particular wetland and showed that location and climate are more important than (but also interact with) the size and composition of the waterfowl community [2]. Here, we used the wetland that showed the highest LPAIV prevalence in the aforementioned study, to more closely explore the interaction between LPAIV and avian host ecology, as well as the influence of the latter on long-term LPAIV prevalence fluctuations. We found seasonal patterns in LPAIV prevalence, with the highest prevalence rates associated to breeding season and autumn migration, matching results from some of the previous studies in Spain and elsewhere, albeit contrasting with others in which the peak of prevalence occurred outside the breeding season $[8,15,18,51-54]$. We encountered strong interannual longitudinal variation in LPAIV prevalence as in other studies [20]. The results from our model revealed these long-term AIV dynamics to be influenced by a complex process of several ecological and environmental drivers that included the size and composition of the Anseriformes breeding community of the wetland. Thus, results from our model suggest that the waterfowl breeding community composition drives long-term fluctuation of AIV prevalence in our wetland study, similarly to results observed in studies in southern Africa [28, 29], as well as for dabbling ducks in Canada where the proportion of hatch year birds (that ultimately depend on the number of breeding pairs) was positively associated with AIV prevalence [8, 23, 28-31, 52-54]. Bird counts revealed a drastic decrease of breeding couples within the Anseriformes during the course of our study, both at the species and taxa level, while numbers of other resident species increased. The breeding pair decline was most dramatic in the mallard (Figure 1).

Previous studies have emphasised the pivotal role of the Anseriformes in AIV epidemiology, especially the mallard in the Northern Hemisphere [55, 56]. The mallard is the most abundant anatid in the Western Palearctic (its natural distribution range) [57]. This widespread distribution is conferred by its high adaptability towards a wide variety of habitats, ranging from natural ecosystems to anthropic environments [57]. Mallards are social birds capable of moving across long distances during migration, especially subpopulations from high latitudes. However, a proportion of its wild population is migratory whereas another is sedentary [58]. This trait may be involved in different responses towards AIV infections, thus influencing prevalence dynamics [22]. A plausible scenario in AIV epidemiology at the Salburua wetland is that migrants could be responsible for introduction of new AIV strains, while residents may be more important for AIV maintenance. The role of breeders as AIV drivers lies in producing susceptible immunologically naïve offspring, as shown by prevalence peaks reported during autumn migration elsewhere [22, 59].

In fact, significant seasonal differences in AIV prevalence were consistently found in our longitudinal study with regards to host phenology. This finding confirmed the existence of seasonal patterns in the epidemiology 
of these viruses in wild ecosystems as stated by other authors [14, 18, 20, 51, 56]. AIV prevalence always peaked during the same periods in waterfowl phenology both inter- and intra-annually in the Salburua wetland (Figure 2, Additional files 1 and 3); namely during breeding season and/or during autumn migration, a temporal trend in AIV prevalence that has also been reported previously $[56,60]$. However, since our sampling strategy consisted of collecting environmental fresh faecal samples alone, respiratory-tract affinity by potential circulating viral strains during the other periods should not be excluded [51, 61].

During autumn migration, migrating birds of differentorigins congregate in large numbers within the same area joining the local avian community, facilitating multiplestrain AIV mixing by host-to-host transmission (within and between species) [18, 62]. Other research groups did not find any relation between AIV detection rates and host density at the species level. However they did when they compared it with the wildfowl community, suggesting aggregation of infection through interspecies mixing reflected in our case study, by the diversity of resident (thus mostly breeding) species [15, 28]. The significant relation of 15 days bs wind with AIV prevalence, also detected by our model, may show the effect of harsh environmental conditions that make the birds remain at the same place rather than scatter, also contributing to host aggregation and locally increased shedding of infectious virus into the environment. AIV detections from wintering populations in the Salburua wetland have been rare, suggesting that prevalence decreases as autumn migration is drawing to an end and more birds have already gained immunity against the circulating viruses [14]. Heterosubtypic immunity may have been protecting the birds against infection from phylogenetically close strains, causing AIV infections to be both less frequent and less diverse during this season and the following spring migration [14, 24]. Nevertheless, AIV has been detected during wintering in Guatemala, The Netherlands, Iran and south central Spain, or during spring migration in Sweden [45, 61, 63-65]. AIV circulation during these periods in some geographical regions could also contribute to year-round virus perpetuation.

Thus, integrating the ecology of both host and LPAIV, a likely scenario is that significantly higher AIV detection rates found during the breeding season and autumn migration are characterised by an input of hosts that are immunologically naïve into the wetland (chicks). The number of offspring is modulated by the number of breeding couples (as a general rule, the more breeding couples the more descendants) and hence, it will have a direct impact on AIV infections (not excluding the emergence of new strains during other periods) $[14,51$,
$56,66]$. Specifically our dataset reflects a decrease in the Anseriformes breeding pairs, while non-Anseriformes breeding pairs increase. As a consequence, the pool of juvenile susceptible individuals at the end of the breeding season may include a similar total number of individuals, but be composed of a higher number of less susceptible (or less-exposed due to their behaviour) individuals (non-Anseriformes). As a result (in addition to other factors such as heterosubtypic immunity etc.), transmission of AIV could be more limited and progressively lead to reduced prevalence [18, 20, 24]. AIV environmental load, potential persistence and transmission among avian hosts will also be negatively affected contributing to a lower AIV global prevalence. In addition, resident species richness and thus breeding sympatry of different species, has an effect on interspecific transmission of AIV. However, the intrinsic properties of each AIV subtype may modulate these host depending factors.

We observed seasonal and temporal variation in AIV subtype prevalence between sampling periods except for $\mathrm{H} 3 \mathrm{~N} 8$, which was detected in both sampling periods. This could reflect the influence of heterosubtypic immunity as stated for mallards in empirical and experimental studies [24]. H3N8 was predominant during breeding season while $\mathrm{H} 11$ subtypes were only detected during autumn migration. A previous study also found these subtypes mainly during autumn migration but in the case of H3N8 also during breeding season and noticed that H3N8 detection was more consistent at the beginning of autumn migration whereas H11 appeared more frequently at the end of the season [14]. A considerable proportion of the AIV detected belonged to LPAIV H5 or H7 subtypes. Mallards harboured the greatest number of AIV positive cases and subtype richness for both periods (Table 4). H7 subtypes were frequently detected during 2009, all harboured by mallards, although no H7 subtype was detected in mallards in northern Europe between 2008 and 2009 [14]. In contrast, H5 was abundant among findings in the Camargue (France) and Northern European birds during the same period while we only detected a single $\mathrm{H} 5$ positive sample (H5N2) [14, 67]. Autumn migration appeared to be the period of the highest subtype richness for both sampling periods, very likely due to a variety of strains brought in by different migrating mallard subpopulations [22].

For AIV surveillance in wild birds, the use of non-invasive sampling techniques such as fresh faeces collection has proven to be a cost-effective tool; large sample sizes can easily be collected from the ecosystem and avian species composition is not discriminated [68]. Capture of birds for swab and blood collection, depending on capture methods, tends to narrow the sample down to specific species and the role of other bird species and 
potential interspecies transmission in terms of AIV-epidemiology may be missed. Hence, the former sampling strategy gives a more realistic picture of which bird species are being infected and when, avoiding at the same time handling and consequently stressing the animals [68]. The drawbacks are that individual infections, respiratory viral shedding, or previous contact with circulating strains based on antibody detection in sera, cannot be monitored. In this regard, although mallard represented at least $44 \%$ of the AIV hosts, it may not necessarily be the only host involved in the epidemiology of the AIV during both sampling periods at this wetland, because other species of ducks, storks and coots were also frequently sampled and to a lower extent gulls, waders and other birds. The low efficiency of the barcoding technique used did not allow the correct host species identification of the remaining AIV positive samples and thus limited our ability to determine the implication of other host species in AIV-epidemiology.

During our sampling-periods no aquatic bird mortality was related to the presence of AIV. In fact, we do not know to what degree the different viral subtypes found during our samplings affect the health status or behaviour of the infected birds. Several studies suggest that LPAIV infections are not pathogenic in their natural reservoir $[9,63]$. In any case, this wetland should be regarded as a hotspot for AIV surveillance considering the hazardous potential of the highly diverse LPAIV H5 and $\mathrm{H} 7$ subtypes found there.

Understanding the influence of host ecology on pathogen transmission is particularly relevant to prevent and manage wildlife disease emergence [28]. From this perspective, we provide a long-term study on AIV epidemiology in a natural ecosystem where prevalence follows seasonal and annual patterns as previously described, but in which long-term prevalence fluctuation is linked to the Anseriformes breeding community composition and size. The use of non-invasive sampling techniques based on environmental samples has proven effective, although an efficient host-identification tool is still necessary to optimise this sampling strategy.

\section{Additional files}

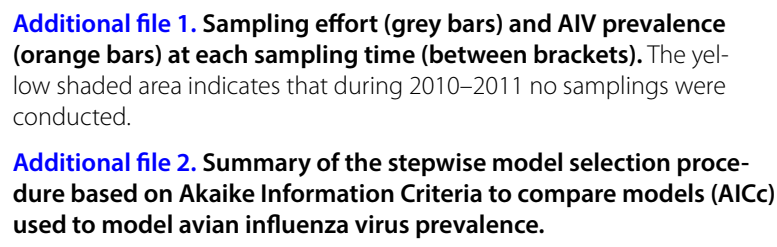

Additional file 2. Summary of the stepwise model selection procedure based on Akaike Information Criteria to compare models (AICC) used to model avian influenza virus prevalence.

Additional file 3. Avian community composition recorded in Salburua wetland. Mean taxonomic order counts and AIV prevalence according to host phenology. During 2010-2011 birds were counted but no samplings for AIV detection were performed.

\section{Abbreviations}

AIV: avian influenza virus; bs: before sampling; COl: mitochondrial cytochrome oxidase subunit 1; GLM: generalized linear model; HA: haemagglutinin; HPAIV: highly pathogenic avian influenza virus; LPAIV: low pathogenicity avian influenza virus; NA: neuraminidase; rRT-PCR: real time reverse transcription polymerase chain reaction; SPF: specific pathogen free; VIF: variance inflation factor.

\section{Competing interests}

The authors declare they have no competing interests.

\section{Authors' contributions}

$\mathrm{MB}$ and $\mathrm{UH}$ conceived the ideas and designed methodology; OT, VA and XG collected and analysed the samples; PA analysed the data; OT, UH and MB led the writing of the manuscript. All authors contributed critically to the drafts. All authors read and approved the final manuscript.

\section{Acknowledgements}

We thank Luis Lobo for providing waterbird census data and technical assistance, and the forest rangers Enrique López, Andoni Candel and Gerezti Unanue for help provided during the samplings, all of them from Green Ring and Biodiversity Unity at Vitoria-Gasteiz City Hall.

\section{Author details}

${ }^{1}$ Animal Health Department, NEIKER-Instituto Vasco de Investigación y Desarrollo Agrario, Parque tecnológico de Bizkaia P-812, 48160 Derio, Bizkaia, Spain. ${ }^{2}$ Grupo SaBio, Instituto de Investigación en Recursos Cinegéticos, IREC (CSICUCLM-JCCM), Ronda de Toledo 12, 13071 Ciudad Real, Spain.

\section{Availability of data and materials}

The dataset supporting the conclusions of this article is available in the Dryad Digital Repository, in https://doi.org/10.5061/dryad.1s15v5b. Raw waterbird census data pertain to wetland authorities and will be available from Green Ring and Biodiversity Unity at Vitoria-Gasteiz City Hall (informacion@vitoriagasteiz.org)

\section{Funding}

This study has been funded by the Instituto Nacional de Investigación y Tecnología Agraria y Alimentaria (INIA) (RTA2011-00111-C03 Grant) and Departamento de Desarrollo Económico e Infraestructuras del Gobierno Vasco. OT was recipient of an INIA predoctoral grant. PA is supported by Ministerio de Economia, industria y competitividad del Gobierno de España and Universidad de Castilla-La Mancha through "Ramón y Cajal" contract (RYC-2012-11970).

\section{Publisher's Note}

Springer Nature remains neutral with regard to jurisdictional claims in published maps and institutional affiliations.

Received: 9 May 2018 Accepted: 20 November 2018

Published online: 17 January 2019

\section{References}

1. Flint J, Racaniello VR, Rall GF, Skalka AM (2015) Principles of virology, $4^{\text {th }}$ edn. ASM Press, Washington

2. Pérez-Ramírez E, Acevedo P, Allepuz A, Gerrikagoitia X, Alba A, Busquets N, Díaz-Sanchez S, Álvarez V, Abad FX, Barral M, Majó N, Höfle U (2012) Ecological factors driving avian influenza virus dynamics in Spanish wetland ecosystems. PLoS One 7:e46418

3. Munster VJ, Wallensten A, Baas C, Rimmelzwaan GF, Schutten M, Olsen B, Osterhaus AD, Fouchier RA (2005) Mallards and highly pathogenic 
avian influenza ancestral viruses, northern Europe. Emerg Infect Dis 11:1545-1551

4. FAO/OIE/WHO Joint Scientific Consultation Writing Committee (2011) Influenza and other emerging zoonotic diseases at the human-animal interface. In: Proceedings of the FAO/OIE/WHO Joint Scientific Consultation, 27-29 April 2010, Verona (Italy). FAO animal production and health proceedings, No. 13. Rome, Italy

5. Adlhoch C, Gossner C, Koch G, Brown I, Bouwstra R, Verdonck F, Penttinen P, Harder T (2014) Comparing introduction to Europe of highly pathogenic avian influenza viruses $A(H 5 N 8)$ in 2014 and $A(H 5 N 1)$ in 2005. Euro Surveill 19:20996

6. Pantin-Jackwood MJ, Costa-Hurtado M, Shepherd E, DeJesus E, Smith D, Spackman E, Kapczynski DR, Suarez DL, Stallknecht DE, Swayne DE (2016) Pathogenicity and transmission of $\mathrm{H} 5$ and $\mathrm{H} 7$ highly pathogenic avian influenza viruses in mallards. J Virol 90:9967-9982

7. Napp S, Majó N, Sánchez-Gónzalez R, Vergara-Alert J (2018) Emergence and spread of highly pathogenic avian influenza $A(H 5 N 8)$ in Europe in 2016-2017. Transbound Emerg Dis 65:1217-1226

8. Olsen B, Munster VJ, Wallensten A, Waldenström J, Osterhaus AD, Fouchier RA (2006) Global patterns of influenza A virus in wild birds. Science 312:384-388

9. Kuiken T (2013) Is low pathogenic avian influenza virus virulent for wild waterbirds? Proc Biol Sci 280:20130990

10. Olson SH, Parmley J, Soos C, Gilbert M, Latorre-Margalef N, Hall JS, Hansbro PM, Leighton F, Munster V, Joly D (2014) Sampling strategies and biodiversity of influenza A subtypes in wild birds. PLoS One 9:e90826

11. Daoust PY, Kibenge FS, Fouchier RA, van der Bildt MW, van Riel D, Kuiken T (2011) Replication of low pathogenic avian influenza virus in naturally infected mallard ducks (Anas platyrhynchos) causes no morphologic lesions. J Wildl Dis 47:401-409

12. Barral M, Alvarez V, Juste RA, Agirre I, Inchausti I (2008) First case of highly pathogenic H5N1 avian influenza virus in Spain. BMC Vet Res 4:50

13. Reperant LA, Osterhaus ADME, Kuiken T (2012) Influenza Virus Infections. In: Gavier-Widén D, Duff JP, Meredith A (eds) Infectious diseases of wild mammals and birds in Europe. Wiley-Blackwell, Chichester

14. Latorre-Margalef N, Tolf C, Grosbois V, Avril A, Bengtsson D, Wille M, Osterhaus AD, Fouchier RA, Olsen B, Waldenström J (2014) Long-term variation in influenza $A$ virus prevalence and subtype diversity in migratory mallards in northern Europe. Proc Biol Sci 281:20140098

15. Hénaux V, Samuel MD, Dusek RJ, Fleskes JP, Ip HS (2012) Presence of avian influenza viruses in waterfowl and wetlands during summer 2010 in California: are resident birds a potential reservoir? PLoS One 7:e31471

16. Brown VL, Drake JM, Stallknecht DE, Brown JD, Pedersen K, Rohani P (2013) Dissecting a wildlife disease hotspot: the impact of multiple host species, environmental transmission and seasonality in migration, breeding and mortality. J R Soc Interface 10:20120804

17. Nallar R, Papp Z, Epp T, Leighton FA, Swafford SR, DeLiberto TJ, Dusek RJ, Ip HS, Hall J, Berhane Y, Gibbs SE, Soos C (2015) Demographic and spatiotemporal patterns of avian influenza infection at the continental scale, and in relation to annual life cycle of a migratory host. PLoS One 10:e0130662

18. Hill NJ, Ma EJ, Meixell BW, Lindberg MS, Boyce WM, Runstadler JA (2016) Transmission of influenza reflects seasonality of wild birds across the annual cycle. Ecol Lett 19:915-925

19. Brown JD, Stallknecht DE (2008) Wild bird surveillance for the avian influenza virus. Methods Mol Biol 436:85-97

20. Avril A, Grosbois V, Latorre-Margalef N, Gaidet N, Tolf C, Olsen B, Waldenström J (2016) Capturing individual-level parameters of influenza A virus dynamics in wild ducks using multistate models. J Appl Ecol 53:1289-1297

21. Risely A, Klaassen M, Hoye BJ (2018) Migratory animals feel the cost of getting sick: a meta-analysis across species. J Anim Ecol 87:301-314

22. Verhagen JH, Van Dijk JGB, Vuong O, Bestebroer T, Lexmond P, Klaassen M, Fouchier RA (2014) Migratory birds reinforce local circulation of avian influenza viruses. PLoS One 9:e112366

23. Verhagen JH, Fouchier RAM, Muster VJ (2011) Ecology of Avian Viruses. In: Hurst CJ (ed) Studies in viral ecology. Animal host systems, vol 2. WileyBlackwell, New Jersey

24. Latorre-Margalef N, Brown JD, Fojtik A, Poulson RL, Carter D, Franca M, Stallknecht DE (2017) Competition between influenza A virus subtypes through heterosubtypic immunity modulates re-infection and antibody dynamics in the mallard duck. PLoS Pathog 13:e1006419

25. Lebarbenchon C, Feare CJ, Renaud F, Thomas F, Gauthier-Clerc M (2010) Persistence of highly pathogenic avian influenza viruses in natural ecosystems. Emerg Infect Dis 16:1057-1062

26. Handel A, Lebarbenchon C, Stallknecht D, Rohani P (2014) Trade-offs between and within scales: environmental persistence and within-host fitness of avian influenza viruses. Proc Biol Sci 281:20133051

27. Caron A, De Garine-Wichatitsky M, Ndlovu M, Cumming GS (2012) Linking avian communities and avian influenza ecology in southern Africa using epidemiological functional groups. Vet Res 43:73

28. Gaidet N, Caron A, Cappelle J, Cumming GS, Balança G, Hammoumi S, Cattoli G, Abolnik C, de Almeida RS, Gil P, Fereidouni SR, Grosbois V, Tran A, Mundava J, Fofana B, El Mamy AB, Ndlovu M, Mondain-Monval JY, Triplet P, Hagemeijer W, Karesh WB, Newman SH, Dodman T (2012) Understanding the ecological drivers of avian influenza virus infection in wildfowl: a continental-scale study across Africa. Proc Biol Sci 279:1131-1141

29. Gaidet N (2016) Ecology of avian influenza virus in wild birds in tropical Africa. Avian Dis 60:296-301

30. Papp Z, Clark RG, Parmley EJ, Leighton FA, Waldner C, Soos C (2017) The ecology of avian influenza viruses in wild dabbling ducks (Anas spp.) in Canada. PLoS One 12:e0176297

31. Mundava J, Caron A, de Garine-Wichatitsky M, Abolnik C, Mundy P, Gaidet N (2016) The role of breeding phenology and aggregation of waterfowl on avian influenza dynamics in southern Africa. Ibis 158:762-775

32. Muñoz PM, Boadella M, Arnal M, de Miguel MJ, Revilla M, Martínez D, Vicente J, Acevedo P, Oleaga A, Ruiz-Fons F, Marín CM, Prieto JM, de la Fuente J, Barral M, Barberán M, Fernández de Luco D, Blasco JM, Gortázar C (2010) Spatial distribution and risk factors of Brucellosis in Iberian wild ungulates. BMC Infect Dis 10:46

33. RAMSAR (2006) Ficha Informativa de los Humedales de Ramsar. Salburua. http://www.ingurumena.ejgv.euskadi.eus/u95aWar/u95aPintaF icheroServlet?R01HNoPortal=true\&idiomaFichero=es\&codigoFich ero $=5004 \&$ tipoFichero $=2 \&$ R01 HNoPortal=true. Accessed 26 Nov 2018

34. Spackman E, Senne DA, Myers TJ, Bulaga LL, Garber LP, Perdue ML, Lohman K, Daum LT, Suarez DL (2002) Development of a real-time reverse transcriptase PCR assay for type A influenza virus and the avian $\mathrm{H} 5$ and H7 hemagglutinin subtypes. J Clin Microbiol 40:3256-3260

35. OIE (2015) Avian influenza (infection with avian influenza viruses). In: Manual of diagnostic tests and vaccines for terrestrial animals 2016. http://www.oie.int/fileadmin/Home/eng/Health_standards/ tahm/2.03.04_Al.pdf. Accessed 4 Oct 2017

36. Elizalde M, Agüero M, Buitrago D, Yuste M, Arias ML, Munoz MJ, Lellic D, Pérez-Ramírez E, Moreno-Martin AM, Fernández-Pinero J (2014) Rapid molecular haemagglutinin subtyping of avian influenza isolates by specific real-time RT-PCR tests. J Virol Methods 196:71-81

37. Hoffmann B, Hoffmann D, Henritzi D, Beer M, Harder TC (2016) Riems influenza a typing array (RITA): an RT-qPCR-based low density array for subtyping avian and mammalian influenza a viruses. Sci Rep 6:27211

38. Aguero M, San Miguel E, Sanchez A, Gomez-Tejedor C, Jimenez-Clavero MA (2007) A fully automated procedure for the high-throughput detection of avian influenza virus by real-time reverse transcription-polymerase chain reaction. Avian Dis 51:235-241

39. Monne I, Ormelli S, Salviato A, De Battisti C, Bettini F, Salomoni A, Drago A, Zecchin B, Capua I, Cattoli G (2008) Development and validation of a one-step real-time PCR assay for simultaneous detection of subtype $\mathrm{H} 5$, $\mathrm{H7}$, and $\mathrm{H} 9$ avian influenza viruses. J Clin Microbiol 46:1769-1773

40. Hoffmann B, Harder T, Starick E, Depner K, Werner O, Beer M (2007) Rapid and highly sensitive pathotyping of avian influenza A H5N1 virus by using real-time reverse transcription-PCR. J Clin Microbiol 45:600-603

41. Payungporn S, Chutinimitkul S, Chaisingh A, Damrongwantanapokin S, Nuansrichay B, Pinyochon W, Amonsin A, Donis RO, Theamboonlers A, Poovorawan Y (2006) Discrimination between highly pathogenic and low pathogenic H5 avian influenza A viruses. Emerg Infect Dis 12:700-701

42. Hoffmann E, Stech J, Guan Y, Webster RG, Perez DR (2001) Universal primer set for the full-length amplification of all influenza A viruses. Arch Virol 146:2275-2289

43. Lijtmaer DA, Kerr KCR, Stoeckle MY, Tubaro PL (2012) DNA barcoding birds: from field collection to data analysis. Methods Mol Biol 858:127-152 
44. Cheung PP, Leung YHC, Chow CK, Ng CF, Tsang CL, Wu YO, Ma SK, Sia SF, Guan Y, Peiris JSM (2009) Identifying the species-origin of faecal droppings used for avian influenza virus surveillance in wild-birds. J Clin Virol 46:90-93

45. Perez-Ramirez E, Gerrikagoitia X, Barral M, Hofle U (2010) Detection of low pathogenic avian influenza viruses in wild birds in Castilla-La Mancha (south central Spain). Vet Microbiol 146:200-208

46. SEO/BirdLife (2008) Enciclopedia de las aves de España. http://www.encic lopediadelasaves.es/. Accessed 4 Oct 2017

47. Svensson L, Mullarney K, Zetterstrom D, Grant PJ (2010) Collins bird guide, 2nd edn. Harper Collins publishers, New York

48. Torrontegui O, Alvarez V, Acevedo P, Gerrikagoitia X, Höfle U, Barral M (2018) Long-term avian influenza virus epidemiology in a small Spanish wetland ecosystem is driven by the breeding Anseriformes community. Dryad Digit Repos. https://doi.org/10.5061/dryad.1s15v5b

49. Zuur AF, leno EN, Elphick CS (2010) A protocol for data exploration to avoid common statistical problems. Methods Ecol Evol 1:3-14

50. Heiberger RM (2012) HH: statistical analysis and data display: Heiberger and Holland. In: R Packag. version

51. Van Dijk JGB, Hoye BJ, Verhagen JH, Nolet BA, Fouchier RA, Klaassen M (2014) Juveniles and migrants as drivers for seasonal epizootics of avian influenza virus. J Anim Ecol 83:266-275

52. Busquets N, Alba A, Napp S, Sánchez A, Serrano E, Rivas R, Núñez JL, Majó N (2010) Influenza A virus subtypes in wild birds in North-Eastern Spain (Catalonia). Virus Res 149:10-18

53. Tolf $C$, Bengtsson $D$, Rodrigues $D$, Latorre-Margalef $N$, Wille M, Figueiredo ME, Jankowska-Hjortaas M, Germundsson A, Duby PY, Lebarbenchon C, Gauthier-Clerc M, Olsen B, Waldenström J (2012) Birds and viruses at a crossroad-surveillance of influenza A virus in Portuguese waterfowl. PLoS One 7:e49002

54. Alba A, Bicout DJ, Vidal F, Curcó A, Allepuz A, Napp A, García-Bocanegra I, Costa T, Casal J (2012) Model to track wild birds for avian influenza by means of population dynamics and surveillance information. PLoS One 7:e44354

55. De Marco MA, Valentini A, Foni E, Savarese MC, Cotti C, Chiapponi C, Raffini E, Donatelli I, Delogu M (2014) Is there a relation between genetic or social groups of mallard ducks and the circulation of low pathogenic avian influenza viruses? Vet Microbiol 170:418-424

56. Munster VJ, Baas C, Lexmond P, Waldenstro J, Wallensten A, Fransson T, Rimmelzwaan GF, Beyer WEP, Schutten M, Olsen B, Osterhaus AD, Fouchier RA (2007) Spatial, temporal, and species variation in prevalence of influenza a viruses in wild migratory birds. PLoS Pathog 3:e61

57. Keawcharoen J, van Riel D, van Amerongen G, Bestebroer T, Beyer W, Van Lavieren R, Osterhaus A, Fouchier R, Kuiken T (2008) Wild ducks as long-distance vectors of highly pathogenic avian influenza virus ( $\mathrm{H} 5 \mathrm{~N} 1$ ). Emerg Infect Dis 14:600-607
58. Van Dijk JGB (2014) Pathogen dynamics in a partial migrant: interactions between mallards (Anas platyrhynchos) and avian influenza viruses. Ph.D. thesis, Utrech University, Utrech, The Netherlands

59. Wallensten A, Munster VJ, Latorre-Margalef N, Brytting M, Elmberg J, Fouchier RA, Fransson T, Haemig PD, Karlsson M, Lundkvist A, Osterhaus AD, Stervander M, Waldenstrom J, Olsen B (2007) Surveillance of influenza A virus in migratory waterfowl in northern Europe. Emerg Infect Dis 13:404-411

60. Henriques AM, Fagulha T, Barros SC, Ramos F, Duarte M, Luis T, Fevereiro M (2011) Multiyear surveillance of influenza A virus in wild birds in Portugal. Avian Pathol 40:597-602

61. Fereidouni SR, Werner O, Starick E, Beer M, Harder TC, Aghakhan M, Modirrousta H, Amini H, Moghaddam MK, Bozorghmehrifard MH, Akhavizadegan MA, Gaidet N, Newman SH, Hammoumi S, Cattoli G, Globig A, Hoffmann B, Sehati ME, Masoodi S, Dodman T, Hagemeijer W, Mousakhani S, Mettenleiter TC (2010) Avian influenza virus monitoring in wintering waterbirds in Iran, 2003-2007. Virol J 7:43

62. Latorre-Margalef N, Grosbois V, Wahlgren J, Munster VJ, Tolf C, Fouchier RA, Osterhaus AD, Olsen B, Waldenström J (2013) Heterosubtypic immunity to influenza A virus infections in mallards may explain existence of multiple virus subtypes. PLoS Pathog 9:e1003443

63. Kleijn D, Munster VJ, Ebbinge BS, Jonkers DA, Müskens GJ, Van Randen Y, Fouchier RA (2010) Dynamics and ecological consequences of avian influenza virus infection in greater white-fronted geese in their winter staging areas. Proc Biol Sci 277:2041-2048

64. Wallensten A, Munster VJ, Karlsson M, Lundkvist A, Brytting M, Stervander M, Osterhaus AD, Fouchier RA, Olsen B (2006) High prevalence of influenza $A$ virus in ducks caught during spring migration through Sweden. Vaccine 24:6734-6735

65. González-Reiche A, Müller M, Ortiz L, Cordón-Rosales C, Perez D (2016) Prevalence and diversity of low pathogenicity avian influenza viruses in wild birds in Guatemala, 2010-2013. Avian Dis 60:359-364

66. Verhagen JH, Munster VJ, Majoor F, Lexmond P, Vuong O, Stumpel JB, Rimmelzwaan GF, Osterhaus AD, Schutten M, Slaterus R, Fouchier RA (2012) Avian influenza a virus in wild birds in highly urbanized areas. PLoS One 7:e38256

67. Lebarbenchon C, Albespy F, Brochet AL, Grandhomme V, Renaud F, Fritz $\mathrm{H}$, Green AJ, Thomas F, van der Werf S, Aubry P, Guillemain M, GauthierClerc M (2009) Spread of avian influenza viruses by common teal (Anas crecca) in Europe. PLoS One 4:e7289

68. Pannwitz G, Wolf C, Harder T (2009) Active surveillance for avian influenza virus infection in wild birds by analysis of avian fecal samples from the environment. J Wildl Dis 45:512-518

\footnotetext{
Ready to submit your research? Choose BMC and benefit from:

- fast, convenient online submission

- thorough peer review by experienced researchers in your field

- rapid publication on acceptance

- support for research data, including large and complex data types

- gold Open Access which fosters wider collaboration and increased citations

- maximum visibility for your research: over $100 \mathrm{M}$ website views per year
}

At BMC, research is always in progress.

Learn more biomedcentral.com/submissions 